\title{
Waste treatment with the pilot scale ATAD and EGSB pig slurry management system followed by sequencing batch treatment
}

\author{
Young-Shin Lee ${ }^{1}$, Gee-Bong $\mathrm{Han}^{{ }^{\dagger}}$ \\ ${ }^{1}$ Department of Environment Engineering, Hanseo University, Seosan 356-706, Republic of Korea \\ ${ }^{2}$ Department of Biosciences and Environmental Engineering, The Catholic University of Korea, Bucheon 420-743, Republic of Korea
}

\begin{abstract}
Experiments for highly concentrated contaminants in pig waste slurry were carried out for the feasibility test of a pilot-scale innovative process scheme of engaging autothermal thermophilic aerobic digestion (ATAD) and expended granular sludge bed (EGSB) followed by sequencing batch reactor (SBR) system. Contaminants in pig waste slurry such as organic substance, total nitrogen (TN), ammonia nitrogen and total phosphorus (TP) contents were successfully reduced in the system. Total volatile solids (TVS) and chemical oxygen demands (COD) for organic matter in the feed were $32.92 \mathrm{~g} / \mathrm{L}$ and $42.55 \mathrm{~g} / \mathrm{L}$ respectively, and they were reduced by about $98.7 \%$ and $99.2 \%$, respectively in the system. The overall removal efficiencies for TN and ammonium nitrogen were found to be 98.1 and $98.5 \%$, respectively. The overall removal efficiency for total phosphorus was also found to be $92.5 \%$. Faecal coliform density was reduced to $<1.2 \times 10^{4} \mathrm{CFU} / \mathrm{g}$ total solids. Biogas and $\mathrm{CH}_{4}$ were produced in the range of $0.39-0.85$ and $0.25-0.62 \mathrm{~m}^{3} / \mathrm{kg}$ [VS removed], respectively. The biogas produced in the system comprised of $295 \pm 26 \mathrm{ppm}(\mathrm{v} / \mathrm{v}$ )
\end{abstract} $\left[\mathrm{H}_{2} \mathrm{~S}\right]$.

Keywords: ATAD, EGSB, nutrients, Pig waste slurry, SBR

\section{Introduction}

Centralized industrial-scale pig farms have led to an excessively concentrated generation of animal waste, which has induced the excessive use of wash-water. The concentrated pig slurry streams from these large-scale pig farms cannot be treated by land-based treatment systems in the land-restricted regions, and alternative treatment options are often required to be developed due to uncontrolled release of nutrients to the watershed [1]. Consequently, wastewater treatment at the dense pig farms in smaller areas has been an ongoing problem caused by highly concentrated organic and inorganic contaminants, viral and bacterial pathogens in piggery waste. Since a wide range of animal waste treatment based on the experience in treating other concentrated industrial waste were applied in pig slurry treatment the engineered animal waste treatment systems require reclamation of chemical and biologically safe nutrient-rich solids, processed water, biogas for energy, and reduction of odor. To address this requirement, many researchers focused on developing efficient unit processes for alternative treat-

This is an Open Access article distributed under the terms of the Creative Commons Attribution Non-Commercial License (http://creativecommons. org/ licenses/by-nc/3.0/) which permits unrestricted non-commercial use, distribution, and reproduction in any medium, provided the original work is properly cited.

Copyright (C) 2015 Korean Society of Environmental Engineers ment schemes instead of traditional methods [2-5]. The most recent approach includes integrated microalgal culture system to treat livestock wastewater which is an efficient implication to reduce the cost of biodiesel production and provide an environmental benefit of microalgal bioremediation [34].

Béline and Martinez [6] reported that $60-70 \%$ of the TN in the untreated pig slurry was reduced by aerobic digestion. Autothermal thermophilic aerobic digestion (ATAD) requires shorter (9-14 days) sludge detention times, and effectively decreases pathogen numbers, thus many researchers focused on ATAD for high level organic wastewater treatment $[7,8]$. The ATAD process was also effective in volatile suspended solid removal [9]. Although anaerobic digestion has potentials of producing energy gas, decreasing odor problems, and reducing pathogen numbers, traditional anaerobic digestion would require the longer hydraulic detention times (HRT) and higher costs of energy requirement for efficient and sustainable digestion [10].

The expanded granular sludge bed (EGSB) reactor is a modified up-flow anaerobic sludge blanket (UASB) reactor in which hydraulic channeling and dead zones were improved. Superficial velocity

Received Jun 9, 2015 Accepted August 10, 2015

${ }^{\dagger}$ Corresponding author

Email: geebhan@catholic.ac.kr

Tel: 82-2-2164-4878 Fax: +82-2-2164-4765 
in EGSB is higher than in UASB due to a high height to diameter ratio and a high recirculation rate. Consequently, these characteristics improve the mixing and the contact between the wastewater and the sludge in the EGSB reactor [3, 11, 12].

More sophisticated systems are being developed for more efficient process with higher biogas productivity and nutrient reduction. Two-stage process associating a faster aerobic thermophilic process and a slower anaerobic mesophilic process is recognized to attain the demands for both efficient organic matter removal and pathogen reduction. Thus, better volatile solids (VS) removal and biogas generation than single mesophilic process could be achieved [13]. Technologies counted on selected combination of unit processes fulfilling the specifically desired treatment are often favored. Thus, a conjugated stage process of ATAD and EGSB with sequencing batch reactor (SBR) system could be one practical alternative to manage the highly contaminated pig waste slurry [14].

In the recent years, many researchers have focused on the SBR for its flexibility and efficient nutrients reduction from livestock waste treatment in one stage processing. Furthermore, this reactor configuration has merits due to its single-reactor operation and compact system. Thus SBR is derived from its nutrient reduction performance for the high nutrients content of pig waste slurry [15-18].

This study has the following objectives to test the capability and efficiency of the innovative pilot-scale process scheme engaging an ATAD and EGSB unit process with SBR system for reduction of highly concentrated contaminants in pig slurry waste on the basis of results obtained. The specific aims of this study were to test: (1) system performance such as reduction of volatile solids (VS), supernatant chemical oxygen demand (COD), total nitrogen (TN), ammonium nitrogen $\left(\mathrm{NH}_{4}{ }^{+}-\mathrm{N}\right)$, and total phosphorus (TP); (2) fecal pathogens reduction; (3) biogas production during pig waste slurry treatment.

\section{Materials and Methods}

\subsection{Operational Process Scheme}

Pilot scale tests were performed to investigate effectiveness of reducing highly concentrated organics and nutrients from pig slurry waste. A schematic diagram of the experimental set-up was shown in Fig. 1.

The pilot scale experimental process consisted of three stages of successive unit systems in series by using the effluent of the previous step to the successive step as influent. The unit process of ATAD with coagulation was tested for the first stage system. The unit process of organic acid feeding and EGSB were used for the second system. SBR was the third stage unit system (Fig. 1). The ATAD and EGSB reactors were cylindrical tanks with working volumes of 9.8 and $3.0 \mathrm{~m}^{3}$, respectively. The EGSB reactor has an internal diameter of $0.6 \mathrm{~m}$ with a height of $11.0 \mathrm{~m}$. Air was bubbled by torus air diffuser through the contents of the ATAD to supply dissolved oxygen contents of $2.6-3.3 \mathrm{mg} / \mathrm{L}$ needed to promote heat generation through metabolic oxidation of the organic matter. The working volume of SBR was $10.0 \mathrm{~m}^{3}$ and operation cycles were controlled by programmable timers. SBR is equipped with a submerged mixer for stirring and a decanter for discharging the clarified effluent.

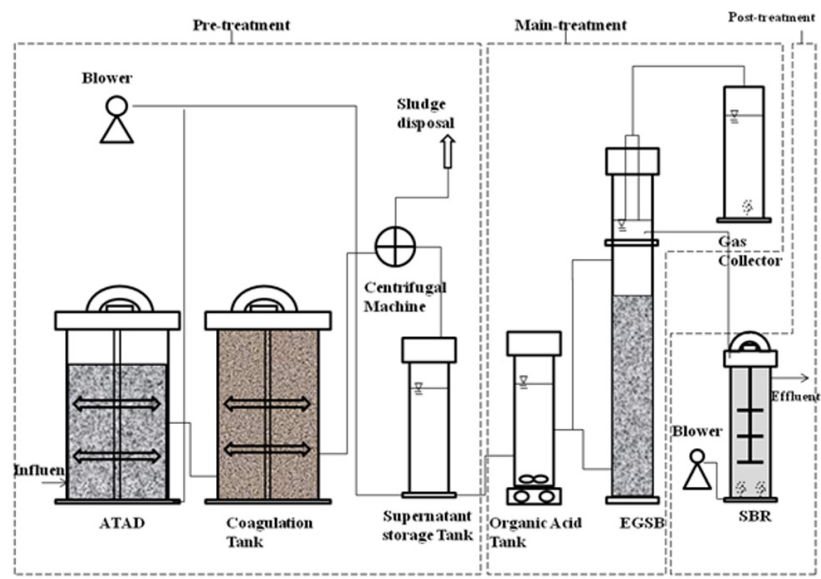

Fig. 1. Schematic diagram of the proposed system.

\subsection{System Description and Operation}

The pilot scale experimental system was supplied with pig waste slurry from a regional group of farmers keeping 6,000 hogs in Seosan-si Chungcheongnam-do, Korea. The raw pig waste slurry was comprised of waste mixtures of feces, urine and washing water, and its characteristics are shown in Table 1. The feed pig slurry composition was monitored for 14 months, and triplicate samples were analyzed in each time for twice per week.

The ATAD unit process was operated at 3-day HRT and a flow rate of $1.0 \mathrm{~m}^{3} / \mathrm{d}$ of pig waste slurry was innoculated with 3.0 $\mathrm{L}$ enrichment medium of Bacillus, and sustained at $55 \pm 1^{\circ} \mathrm{C}$. At the first stage with the ATAD treatment, a portion of the pig waste slurry withdrawn was simultaneously transported into the coagulation system, and $500 \mathrm{mg} / \mathrm{L}$ of coagulant (Califloc; Outriger co, Korea) with $75 \mathrm{mg} / \mathrm{L}$ of high molecular sub-coagulant (cation-polymer flocculent) were dosed to flocculate top suspended solids. Then the supernatant isolated from the coagulated sludge by gravity centrifugation was sent to the organic acid tank located front of the EGSB system to prohibit organic shock loading.

The EGSB system with $3.0 \mathrm{~m}^{3}$ working volume was inoculated with $0.6 \mathrm{~m}^{3}$ (20\% of reactor working volume) of mesophilic granular sludge derived from an UASB tank treating sewage. After inoculation of the system, the granular sludge was acclimated to give 13.1g TS/L and 9.2g VS/L in the liquid volume of the reactor for three weeks. The experimental systems were operated for an

Table 1. Characteristics of Feed Pig Slurry

\begin{tabular}{lccc}
\hline \multicolumn{1}{c}{ Item } & Minimum & Maximum & Average \\
\hline $\mathrm{pH}$ & 7.4 & 7.9 & $7.6 \pm 0.1$ \\
$\mathrm{COD}(\mathrm{g} / \mathrm{L})$ & 28.20 & 74.30 & $42.55 \pm 1.25$ \\
$\mathrm{TS}(\mathrm{g} / \mathrm{L})$ & 34.50 & 61.80 & $48.0 \pm 1.72$ \\
$\mathrm{VS}(\mathrm{g} / \mathrm{L})$ & 21.80 & 54.23 & $32.92 \pm 1.63$ \\
$\mathrm{TN}(\mathrm{g} / \mathrm{L})$ & 2.55 & 6.73 & $5.08 \pm 0.10$ \\
$\mathrm{NH}_{4}^{+}{ }^{+} \mathrm{N} \mathrm{(g/L)}$ & 1.89 & 4.99 & $3.68 \pm 0.64$ \\
$\mathrm{TP}(\mathrm{g} / \mathrm{L})$ & 0.49 & 1.31 & $1.12 \pm 0.045$ \\
Faecal coli form & $7.4 \times 10^{7}$ & $9.9 \times 10^{7}$ & $9.2 \times 10^{7} \pm 0.8 \times 10^{6}$ \\
$(\mathrm{CFU} / \mathrm{g}[\mathrm{TS}])$ & & & \\
\hline
\end{tabular}


initial period of 30 days prior to data collection for evaluation of the systems. The separated supernatant from the organic acid tank was continuously fed to the EGSB reactor, the second unit system in the treatment process. Influent was supplied with using a feeding pump at a flow rate of $1.0 \mathrm{~m}^{3} / \mathrm{d}$, and effluent was sent back to fluidize the bed at an adequate up-flow superficial velocity. During the start-up, the organic loading rate (OLR) was slowly lifted up from 5.0 to $16.5 \mathrm{~kg} \mathrm{COD} / \mathrm{m}^{3} / \mathrm{d}$, and the linear superficial velocity of up-flow was also raised from 0.1 to $0.45 \mathrm{~m} / \mathrm{h}$. The EGSB system was operated under mesophilic condition $\left(35 \pm 1^{\circ} \mathrm{C}\right)$ and buffered by alkaline compounds $\left(\mathrm{NaCO}_{3}, \mathrm{NaHCO}_{3}\right.$, and $\left.\mathrm{Ca}(\mathrm{OH})_{2}\right)$ and the refluxing of the effluent at $\mathrm{pH}$ 7.4-8.0 to intensify the growth rate of the anaerobic bacteria. The third stage unit system was the nutrient reduction system adopting a sequencing batch reactor (SBR). During the entire test, one cycle of SBR was comprised of $6 \mathrm{~h}$ operation, and two hours of aeration and one hour of non-aeration per one cycle were performed. Parameters for operation of all unit systems are listed in Table 2 .

\subsection{Sampling and Analytical Methods}

The ATAD and EGSB effluent samples were analyzed for total solids (TS), TVS, and chemical oxygen demand (COD). Sodium metaphosphate buffer (2 g/L; $\mathrm{pH}$ 6.8) was used to dilute samples by 1:10 for feed piggery waste, ATAD, faecal coliform density, EGSB and SBR reactors. The removal efficiency, in terms of contaminants in different forms, is calculated by dividing the difference between the concurrent inlet and the treated outlet by the concurrent inlet, and then multiplying by 100. For quantification of faecal coliforms, faecal coliforms were counted as colonies in case of producing a distinctive indigo blue color when $\mathrm{mFC}$ agar (Difco; Voigt, USA) plates were utilized for incubation at $44.5{ }^{\circ} \mathrm{C}$ for $18-20 \mathrm{~h}$. The water displacement method was used to measure biogas generation from the testing digesters. Kitagawa detector for toxic gas (Model 8014KA, MSI, USA) was used to measure hydrogen sulfide. Methane content was analyzed by a Shimadzu GC (Model GC-14C, Dongil Shimadzu, Korea), equipped with a thermal conductivity detector (Dongil Shimadzu, Korea) and a stainless column of Porapak Q (length, 2m; inner diameter, 3mm) (Restek, USA). A carrier gas $\left(\mathrm{H}_{2}\right)$ was provided at a flow rate of $15 \mathrm{ml} \mathrm{min}^{-1}$. A YSI 58 DO meter (Aqua Science, Korea) was used to measure dissolved oxygen (DO) content and $\mathrm{pH}$ was monitored by using a $\mathrm{pH}$ meter of Orion model 3STAR (Aqua Science, Korea). COD, VS, $\mathrm{NH}_{4}{ }^{+}-\mathrm{N}$, TN, TS and TP analyses were conducted by following the methods described in the Standard Methods (APHA, 1998) [19].

\section{Results and Discussion}

\subsection{TVS Reduction}

To evaluate the system performance for the feed pig waste slurry treatment, the reduction in TVS was obtained and shown in Fig. 2.

Fig. 2(a) shows the increasing TVS reduction levels in the ATAD reactor during the start-up phase. The TVS removal efficiency decreased suddenly after 50 days of operation due to increased loading. After 70 days of operation, a TVS removal efficiency of more than $35 \%$ and a TVS concentration of less than $25.0 \mathrm{~g} / \mathrm{L}$ stabilized. In the first unit process system (ATAD and coagulation), the average feed TVS concentration of $3.29 \%$ was reduced by $63.6 \%$ (Fig. 2(b)). Abundant organic contaminants and high temperature $\left(55^{\circ} \mathrm{C}\right)$ seemed to contribute the higher decrease in TVS by more vigorous metabolism in the ATAD of the pre-treatment, which helped fast growth of thermophiles. The organic matter content in the pig waste slurry degraded within 2-3 days of aeration during the thermophilic aerobic digestion process then separated from the supernatant by coagulation. During sludge digestion, the VS reduction can be the most significant indicator of the system performance [20].

In the second unit process system (organic acid tank and EGSB reactor) for the main-treatment, $89.8 \%$ of VS transferred from the first-stage was reduced, corresponding to overall reduction of $32.7 \%$ TVS in the feed pig slurry (Fig. 2(b)). The TVS removal efficienct achieved in the third unit process system (SBR) was found to be $64.9 \%$, which resulted in overall $2.4 \%$ reduction in TVS of the feed pig waste slurry (Fig. 2(b)). As a result, 98.7\% total TVS

Table 2. Operating Parameter Specifications of the Proposed Unit Process

\begin{tabular}{|c|c|c|}
\hline Unit system & Operating parameters & Operating conditions \\
\hline \multirow[t]{5}{*}{ ATAD } & $\operatorname{HRT}(\mathrm{d})$ & 3 \\
\hline & Temperature $\left({ }^{\circ} \mathrm{C}\right)$ & $55 \pm 1$ \\
\hline & $\mathrm{pH}$ & $7.5-8.1$ \\
\hline & Air flow $\left(\mathrm{m}^{3} / \mathrm{min}\right)$ & 85.2 \\
\hline & Inflow of semi-batch mode $\left(\mathrm{m}^{3}\right)$ & 1 \\
\hline \multirow[t]{2}{*}{ Coagulation } & Coagulant (Califloc) (mg/L) & 500 \\
\hline & Flocculant (cation-polymer) (mg/L) & 75 \\
\hline \multirow[t]{5}{*}{ EGSB } & Organic loading rate (kg [COD] $\left./ \mathrm{m}^{3} / \mathrm{d}\right)$ & $5.0-16.5$ \\
\hline & Line up flow velocity $(\mathrm{m} / \mathrm{h})$ & $0.1-0.45$ \\
\hline & Temperature $\left({ }^{\circ} \mathrm{C}\right)$ & $35 \pm 1$ \\
\hline & $\mathrm{pH}$ & $7.4-8.0$ \\
\hline & Flow rate $\left(\mathrm{m}^{3} / \mathrm{d}\right)$ & 1 \\
\hline \multirow[t]{4}{*}{ SBR } & Number of Intermittent aeration/Idle (h/h) & $7(2 / 1)$ \\
\hline & Settle $(\mathrm{h})$ & 1 \\
\hline & Decant \& Discharge (h) & 1 \\
\hline & Feed (h) & 1 \\
\hline
\end{tabular}



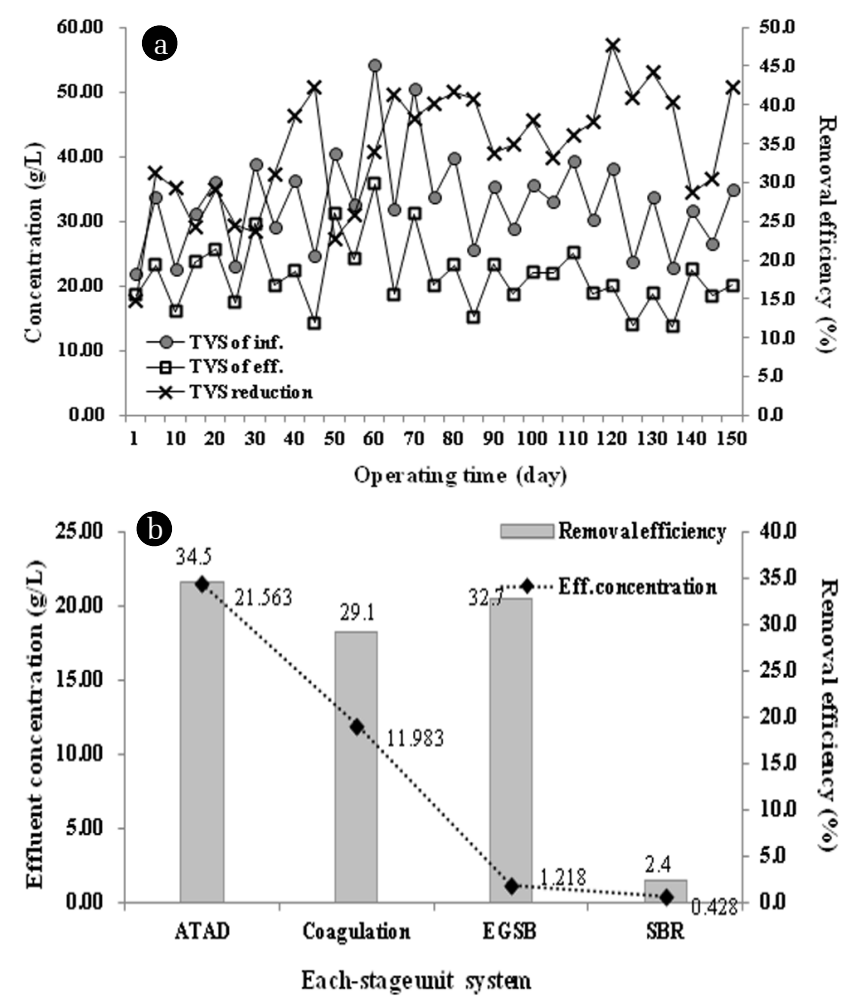

Fig. 2. Reduction in TVS (a) in the ATAD, and (b) at each stage unit system.

in the feed was found to be reduced as total organic degradable solids in the pig waste slurry slowly decreased.

\subsection{COD Reduction}

To evaluate the system performance for pig waste slurry treatment in the feed, the COD reduction was also obtained and shown in Fig. 3.

The inflow rates to the ATAD and EGSB reactor were same as $1.0 \mathrm{~m}^{3} / \mathrm{d}$, and COD concentrations in the feed pig waste slurry to each unit process system were 42.550 and $16.424 \mathrm{~g} / \mathrm{L}$, respectively. After aerobic digestion and separation by coagulation and centrifuge where major fraction of solids was removed (61\%), more liquid manure fraction than the feed pig slurry was processed in the EGSB reactor for reduction of total residual COD (Fig. 3(b)). Thus COD loading to EGSB unit by the inflow rate corresponded to organic loading rate (OLRv) of $3.0-16.5 \mathrm{~kg} \mathrm{COD} / \mathrm{m}^{3} / \mathrm{d}$ at HRT of 1 day. Fig. 3(a) shows the COD reduction levels in the ATAD reactor during the start-up phase. The COD removal efficiency was less than $30 \%$ but after 65 days of operation, a COD removal efficiency of more than $40 \%$ and a COD concentration of less than $30.0 \mathrm{~g} / \mathrm{L}$ stabilized. This reason might be the increased rate of particulate hydrolysis due to the growing microbial population, leading to a release of more biodegradable materials that contribute to the temporary rise of COD in the treated waste. The treated waste COD reflected both the hydrolyzed particulate and soluble organic matter in the feed waste. TVS degraded into the supernatant at the first unit process system, releasing a lot of organic matters such as proteins, nucleic acid, polysaccharides and lipids, and
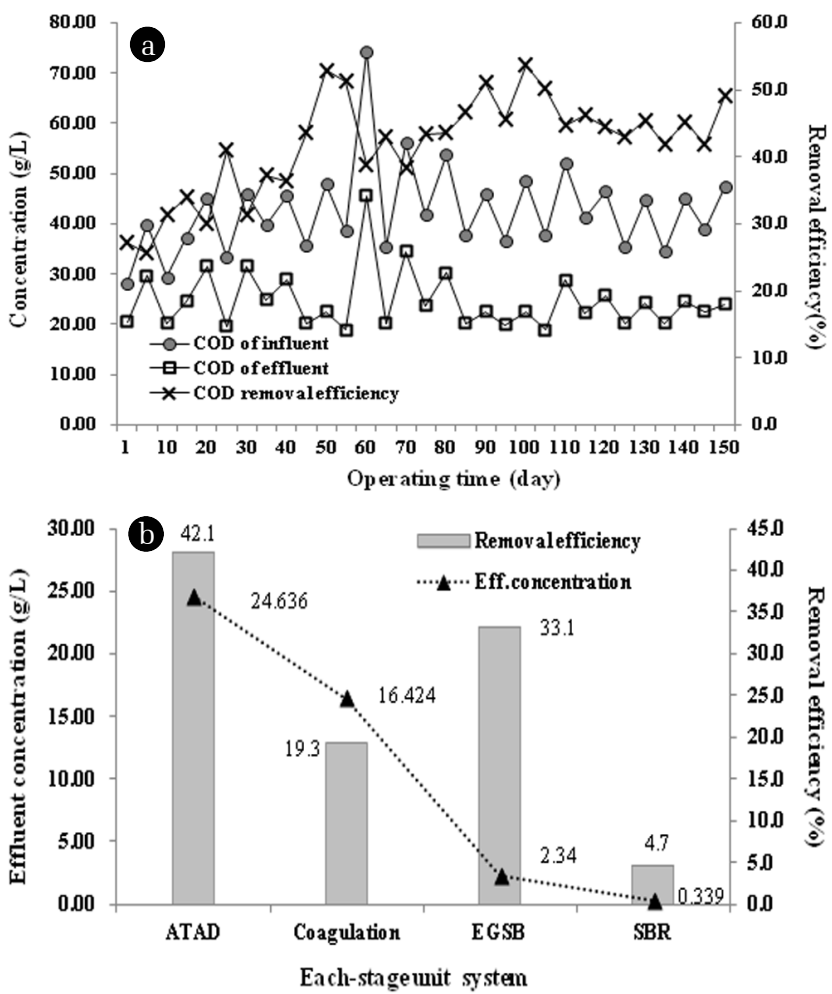

Fig. 3. Reduction in COD (a) in the ATAD reactor, and (b) at each unit process system.

a higher COD removal efficiency was obtained at the first unit process system [21].

During the first unit process system (ATAD), aeration caused the highest degradation of organic matter within 2-3 days, which brought the large amount of COD increase in organic matter [20]. The destruction of cells by heat treatment released proteases, and thermophilic microorganisms could have used compounds released by other microorganisms and achieved rapid growth [22]. During the sludge digestion process, thermo-stable enzymes enhanced the degradation rate [23]. Thus the COD reduction could be enhanced by the organic matters degraded in the ATAD before transporting to next stage (Fig. 3(a)).

In the second unit process system (EGSB), COD in the treated waste from ATAD had decreased to $2.34 \mathrm{~g} / \mathrm{L}$, corresponding to $33.1 \%$ reduction of the feed untreated waste slurry (Fig. 3(b)). Different liquid up-flow velocities were applied using effluent recirculation from 0.1 to $0.45 \mathrm{~m} / \mathrm{h}$ and the increased superficial velocity enhanced the COD reduction in the EGSB, which designated the important role of optimum hydraulic mixing rate. The COD reduction were earned to be $61.4,33.1,4.7 \%$ of the feed pig waste COD at each unit process system of ATAD, EGSB, and SBR reactor (Fig. 3(b)), respectively, and thus COD reduction in the treated pig waste slurry along with TVS reduction in the feed shows the organic matter reduction earned in the combined system. As a consequence, the overall $99.2 \%$ of COD content was reduced by the system.

\subsection{Nutrients Reduction}

The reduction in $\mathrm{TN}$ and $\mathrm{NH}_{4}{ }^{+}-\mathrm{N}$ for the pig slurry treatment 


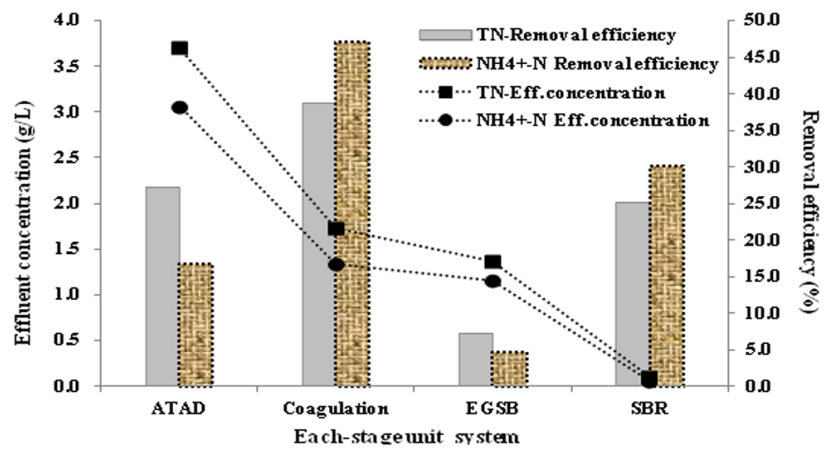

Fig. 4. Reductions in $\mathrm{TN}$ and $\mathrm{NH}_{4}{ }^{+}-\mathrm{N}$ at each unit process system.

are also shown in Fig. 4. The initial ratio of $\mathrm{NH}_{4}{ }^{+}-\mathrm{N} / \mathrm{TN}$ in the feed was about 0.72 but reached up to 0.83 after 3 days of operation. The concentrations of $\mathrm{NH}_{4}{ }^{+}-\mathrm{N}$ and $\mathrm{TN}$ in the suspension increased in the first stage of digestion in ATAD, probably due to the decomposition of protein in extracellular polymeric material and the degradation of temperature intolerant cells [23-25]. Thus, $3.68 \mathrm{~g}$

$\mathrm{NH}_{4}{ }^{+}-\mathrm{N} / \mathrm{L}$ and $5.08 \mathrm{~g}$ TN/L in the suspension attained concentrations of 3.703 and $3.065 \mathrm{~g} / \mathrm{L}$, respectively, in ATAD (Fig. 4). Furthermore, $\mathrm{NH}_{4}{ }^{+}-\mathrm{N}$ was the predominant element of the TN in the suspension, with the ratio of $\mathrm{NH}_{4}{ }^{+}-\mathrm{N} / \mathrm{TN}$ commonly reaching above 0.75 and even increasing up to 0.83 after 3 days of operation. Willer et al. [26] reported that ammonia is mainly released from the organic nitrogen substances in the waste as nitrification and denitrification were inhibited in thermophilic aerobic digestion. The concentration of $\mathrm{NH}_{4}{ }^{+}-\mathrm{N}$ and $\mathrm{TN}$ in the first unit process system had decreased to 1.335 and $1.737 \mathrm{~g} / \mathrm{L}$, corresponding to removal efficiencies of 63.7 and $65.8 \%$, respectively, compared with that of the feed pig waste slurry (Fig. 4). As the digestion process continued, the reduction of the biodegradable organic matter in TVS was no longer important, so the $\mathrm{pH}$ sustained near neutral.

In the second unit process system (EGSB), the remaining $\mathrm{NH}_{4}{ }^{+} \mathrm{N}$ and TN were decreased further to 1.162 and $1.371 \mathrm{~g} / \mathrm{L}$, corresponding to removal efficiencies of 4.7 and $7.2 \%$, respectively (Fig. 4). By the third unit process system (SBR) with consecutive processes of nitrification-denitrification, rest of all TN and $\mathrm{NH}_{4}{ }^{+}-\mathrm{N}$ components were decreased to $97 \mathrm{TN} \mathrm{mg} / \mathrm{L}$ and $54 \mathrm{NH}_{4}{ }^{+}-\mathrm{N} \mathrm{mg} / \mathrm{L}$. Thus, 92.9 and $95.4 \%$ of the $\mathrm{TN}$ and $\mathrm{NH}_{4}{ }^{+}-\mathrm{N}$ in the effluent transferred from EGSB reactor were reduced by the SBR reactor, respectively.

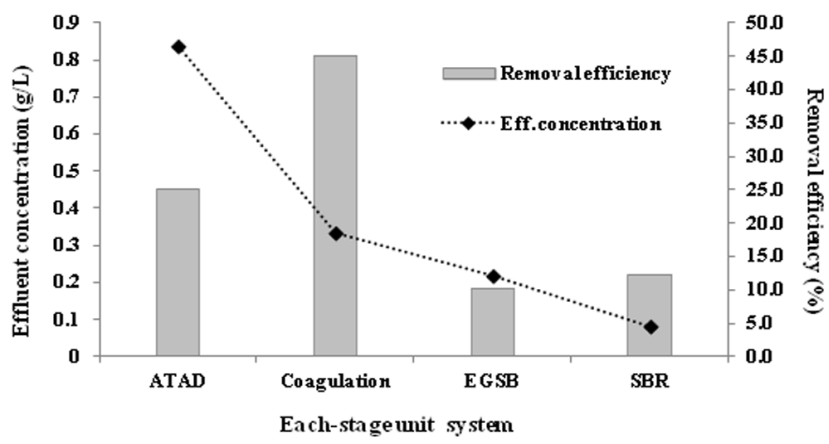

Fig. 5. Reduction in TP at each unit process system.

As a consequence, the overall 98.1 and $98.5 \%$ of $\mathrm{TN}$ and $\mathrm{NH}_{4}{ }^{+}-\mathrm{N}$ components were reduced by the system, respectively.

The TP reduction for the pig waste slurry treatment is also shown in Fig. 5.

The first unit process system of phosphorus removal showed a decrease in TP concentration from 1.12 to $0.335 \mathrm{~g}$ TP/L during the ATAD and coagulation process (Fig. 5). After aerobic digestion and separation by decanter centrifuge where major fraction of phosphate is removed (70\%), this concentration reduced further to $0.22 \mathrm{~g} / \mathrm{L}$, corresponding to $10.3 \%$ of reduction in the influent suspension in the second unit process system (EGSB) (Fig. 5). $61.8 \%$ reduction of TP concentration was achieved by the third unit process system (SBR). Lee et al. [33] reported that the phosphorus accumulation into sludge content through the aerobic and anaerobic conditions in SBR unit could be earned to the maximum $7.1 \%$ of MLVSS. Thus excess sludge containing TP was removed from the system boundary and thus the effluent concentration reached $0.084 \mathrm{~g} \mathrm{TP/L}$ (Fig. 5). As a result, the overall TP removal rate of $92.5 \%$ was also accomplished by the system.

\subsection{Overall Mass Balance at Each Unit Process System}

The overall mass balance for the system performance was assessed with respect to the load at each unit process system. The removal rate was evaluated as the reduction efficiency of mass load for each unit process system. The removal rate and overall mass balance at each unit process system are listed in Table 3.

The overall removal efficiencies of 98.7 and $99.2 \%$ for TVS and COD, respectively, were predominantly attained by ATAD,

Table 3. Removal Rate and Overall Mass Balance at Each Unit Process System

\begin{tabular}{|c|c|c|c|c|c|c|c|c|c|c|}
\hline \multirow{2}{*}{ Unit system } & \multicolumn{2}{|c|}{ TVS } & \multicolumn{2}{|c|}{ COD } & \multicolumn{2}{|c|}{ TN } & \multicolumn{2}{|c|}{$\mathrm{NH}_{4}{ }^{+}-\mathrm{N}$} & \multicolumn{2}{|c|}{ TP } \\
\hline & (g) & $(\%)$ & (g) & $(\%)$ & (g) & (\%) & (g) & (\%) & (g) & $(\%)$ \\
\hline Input & 32.92 & 100 & 42.55 & 100 & 5.08 & 100 & 3.68 & 100 & 1.120 & 100 \\
\hline $1^{\text {st }}$-stage (ATAD) & 11.36 & 34.5 & 17.91 & 42.1 & 1.38 & 27.1 & 0.62 & 16.7 & 0.282 & 25.2 \\
\hline Coagulation & 9.58 & 29.1 & 8.21 & 19.3 & 1.97 & 38.7 & 1.73 & 47.0 & 0.503 & 44.9 \\
\hline $2^{\text {nd }}$-stage (EGSB) & 10.77 & 32.7 & 14.08 & 33.1 & 0.37 & 7.2 & 0.17 & 4.7 & 0.115 & 10.3 \\
\hline $3^{\text {rd }}$-stage (SBR) & 0.79 & 2.4 & 2.0 & 4.7 & 1.27 & 25.1 & 1.11 & 30.1 & 0.136 & 12.1 \\
\hline Output & 0.43 & 1.3 & 0.34 & 0.8 & 0.1 & 1.9 & 0.05 & 1.5 & 0.084 & 7.5 \\
\hline Overall & - & 98.7 & - & 99.2 & - & 98.1 & - & 98.5 & - & 92.5 \\
\hline
\end{tabular}

* (g): reduced amount of contaminant at each stage

(\%): overall reduction rate at each stage 
coagulation and EGSB unit process systems. Overall nitrogen removal efficiencies were also earned to be 98.5 and $98.1 \%$ for $\mathrm{NH}_{4}{ }^{+}-\mathrm{N}$ and TN, respectively, in the system. These nutrients were mainly reduced by coagulation, $\mathrm{NH}_{3}$ gas, and nitrification-denitrification consecutive processes. TP removal was also attained by sludge disposal of luxury-uptake and coagulation, so, an overall removal efficiency of $92.5 \%$ was achieved.

\subsection{Control and Reduction of Pathogen}

The mean concentration of faecal coliforms was analyzed to be $9.2 \times 10^{7} \mathrm{CFU} / \mathrm{g}$ [TS] in the feed pig waste slurry and was in higher level than the reported concentrations [27]. During the first unit process, concentration of faecal coliforms decreased to about $1.2 \times 10^{4} \mathrm{CFU} / \mathrm{g}$ [TS] in the ATAD could be attributed to the thermophilic step in the ATAD unit system. The faecal coliform density of the municipal waste sludge was reduced from about $10^{8}$ to about $10^{4} \mathrm{MPN} / \mathrm{g}$ [TS] by the 1-day SRT thermophilic reactor [28]. The pathogen concentrations decreased from $10^{6}$ to under detectable concentrations within $4 \mathrm{~h}$ at thermophilic temperatures $[29,30]$. These previous results explain that the temperature and duration of digestion could be effective parameters for the reduction of faecal coliforms density during aerobic process digestion.

During the third-stage treatment, the supernatant was intermittently aerated in the SBR reactor through following a successive phase of aerobic and anaerobic conditions that impacted microbial survive. In the SBR reactor of the third unit process system, successive alternation of oxic and anoxic conditions has impact to the conditions for declining faecal coliforms density in liquid slurry waste. Vanotti et al. [31] reported that the nitrificatione-denitrification reaction by alternating oxic and anoxic conditions showed an effective impact for decreasing faecal coliforms in liquid pig waste. As a result, density of faecal coliforms decreased to lower detectable level, and thus no colonies to detect at the higher threshold limit value of $<2 \mathrm{CFU} / \mathrm{mg}$ [TS] were found.

\subsection{Biogas and Methane Generation}

Trends of mean biogas and methane generation obtained from EGSB of the second unit process system are designated in Fig. 6.

A correlation between the TVS and the biogas generation was monitored during 150 experimenting days. Biogas started to be produced after 55 days from the start of the experiment. The average contents of biogas and methane produced were in the range of 0.39-0.85 and $0.25-0.62 \mathrm{~m}^{3} / \mathrm{kg}$ [TVS] destroyed from the EGSB reactor, respectively. The biogas generation from the third unit process system attained a maximum of $0.85 \mathrm{~m}^{3} / \mathrm{kg}$ [TVS] removed after 115 days of test, but the methane generation initialized at $38.5 \%$ of biogas content then attained a maximum of average $72.9 \%$ of biogas content after 115 days of test.

At the second unit process system (EGSB), $\mathrm{H}_{2} \mathrm{~S}$ content in the biogas was found to be relatively low concentration of $295 \pm 26$ ppm (v/v). $\mathrm{H}_{2} \mathrm{~S}$ content in the biogas can be a reason of extra further scrubbing for reuse, and the corrosive effect of the gas. The lower the $\mathrm{H}_{2} \mathrm{~S}$ concentration in the biogas, the more valuable it is for energy regeneration. This study results showed similarity with previous reports that air-stripping of $\mathrm{H}_{2} \mathrm{~S}$ from the waste

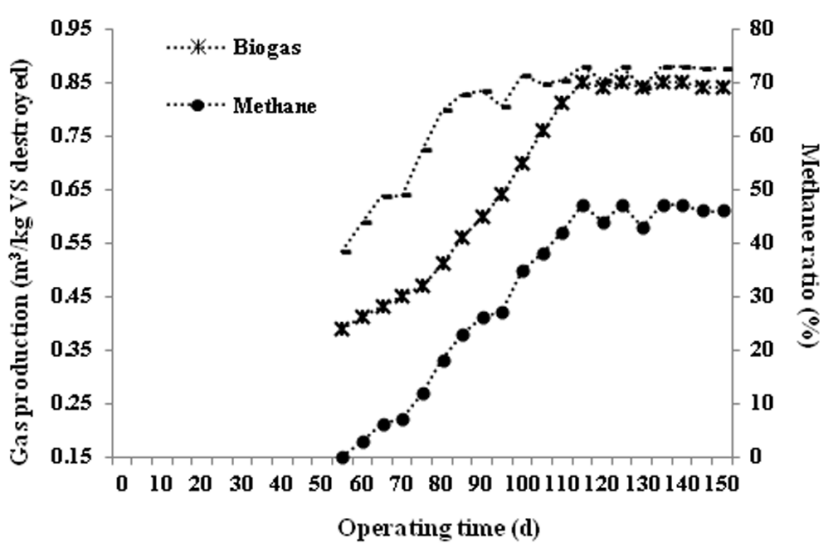

Fig. 6. Trends of mean biogas and methane generation by the system.

slurry in the aerobic thermophilic digester was effective to decrease the $\mathrm{H}_{2} \mathrm{~S}$ levels from the following anaerobic digester in the two unit system biogas [28, 32].

\section{Conclusions}

The effective treatments can decrease pathogens level, contaminants levels and manure volume, and odor potential. This study suggested the effective strategic process scheme for piggery waste slurry control for the management of pollutants at high concentration. The proposed system used in this study showed a way of controlled environmental management strategy and contaminants reduction.

Overall removal efficiencies of $98.7 \%$ for TVS, 99.2\% for COD, 98.1\% for TN, $98.5 \%$ for $\mathrm{NH}_{4}{ }^{+}-\mathrm{N}$ and $92.5 \%$ for TP were attained from feed concentration levels of $32.92 \mathrm{~g} / \mathrm{L}$ [TVS], $42.55 \mathrm{~g} / \mathrm{L}$ [COD], $\left.5.08 \mathrm{~g} / \mathrm{L}[\mathrm{TN}], 3.68 \mathrm{~g} / \mathrm{L} \mathrm{NH}_{4}{ }^{+} \mathrm{N}\right]$ and $1.12 \mathrm{~g} / \mathrm{L}$ [TP] without supplementary dilution. Pathogen was also reduced subsequently by this system during the treatment. No colonies were appeared to be counted at the higher threshold limit of $<2 \mathrm{CFU} / \mathrm{mg}$ [TS], and thus faecal coliform decline resulted in $1.2 \times 10^{4} \mathrm{CFU} / \mathrm{g}$ [TS]. The mean contents of methane and biogas generated were in the ranges of $0.39-0.85$ and $0.25-0.62 \mathrm{~m}^{3} / \mathrm{kg}$ [TVS] destroyed, respectively, and some portion of the organic substance was utilized in the ATAD for heat production.

As a result, the proposed process scheme showed the possibility of using ATAD, EGSB, coagulation and SBR unit process system as an alternative technology for the control of piggery waste treatment. This system showed the successful development of an integrated process to environmental constraints. The effluent polishing with symbiotic bacteria-microalgal treatment might be effective in the future for further treatment of the economic control of residual nutrients still left over in the system.

\section{Acknowledgements}

This study was supported by the Research Fund 2014 of The Catholic University of Korea and Hanseo University. 
Nomenclature

\begin{tabular}{|c|c|c|c|}
\hline \multicolumn{2}{|r|}{ Analytical parameters } & \multicolumn{2}{|r|}{ Operating parameters } \\
\hline CFU & Colony forming unit & DO & Dissolved oxygen, mg/L \\
\hline COD & Chemical oxygen demand, g/L & HRT & Hydraulic retention time, $\mathrm{d}$ \\
\hline MPN & Most probable number, coliforms $100 / \mathrm{ml}$ & MLVSS & Mixed liquor volatile suspended solids, mg/L \\
\hline $\mathrm{TN}$ & Total nitrogen, g/L & OLR & Organic loading rate, $\mathrm{kg} / \mathrm{m}^{3} / \mathrm{d}$ \\
\hline $\mathrm{TP}$ & Total phosphorus, g/L & SRT & Solid retention time, $\mathrm{d}$ \\
\hline TS & Total solids, g/L & & \\
\hline VS & Volatile solids, g/L & & \\
\hline
\end{tabular}

\section{References}

1. Deng L, Cai C, Chen Z. The treatment of pig slurry by a full-scale anaerobic-adding raw wastewater-intermittent aeration process. Biosys. Eng. 2007;98:327-334

2. Vanotti MB, Szogi AA, Hunt PG, Millner PD, Humenik FJ. Development of an environmentally superior treatment system to replace anaerobic swine lagoons in the USA. Bioresour. Technol. 2007;98:3184-3194.

3. Lopez-Fernandeza R, Aristizabal C, Irusta R. Ultrafiltration as an advanced tertiary treatment of anaerobically digested swine manure liquid fraction: A practical and theoretical study. J. Memb. Sci. 2012;375:268-275.

4. Ippersiel D, Mondor M, Lamarche F, Tremblay F, Dubreuil J, Masse L. Nitrogen potential recovery and concentration of ammonia from swine manure using electrodialysis coupled with air stripping. J. Env. Manage. 2012;95:165-169

5. Riaño B, García-González MC. On-farm treatment of swine manure based on solid-liquid separation and biological nitrification-denitrification of the liquid fraction. J. Env. Manage. 2014;132: 87-93

6. Béline F, Martinez J. Nitrogen transformations during biological aerobic treatment of pig slurry: effect of intermittent aeration on nitrous oxide emissions. Bioresour. Technol. 2002;83:225-228.

7. Kelly HG, Mavinic DS. Autothermal Thermophilic Aerobic Digestion Research Application and Operational Experience. In: WEFTEC 2003 Workshop W104 Thermophilic Digestion; 2003 Nov 11; Los Angeles.

8. Park CH, Bae YS, Han GB. Implementation of an excess sludge reduction step in an activated sludge process. J. Env. Sci. Heal. Part A 2010; 45:709-718.

9. Mavinic DS, Mahendraker V, Sharma A, Kelly HG. Effect of microaerophilic conditions on autothermal thermophilic aerobic digestion process. J. Env. Eng. 2001;127:311-316.

10. Hansen KH, Angelidaki I, Ahring BK. Improving thermophilic anaerobic digestion of swine manure. Water Res. 1999;33: 1805-1810.

11. O'Reilly C, Colleran E. Microbial sulphate reduction during anaerobic digestion: EGSB process performance and potential for nitrite suppression of SRB activity. Water Sci. Technol. 2005;52:371-376.

12. Veeresh GS, Kumar P, Mehrotra I. Treatment of phenol and cresols in up-flow anaerobic sludge blanket (UASB) process: a review. Water Res. 2005;39:154-170.
13. Karakashev D, Schmidt JE, Angelidaki I. Innovative process scheme for removal of organic matter, phosphorous and nitrogen from pig manure. Water Res. 2008;42:4083-4090.

14. Lee YS, Han GB. Pig slurry treatment by a hybrid multi-stage unit system consisting of an ATAD and an EGSB followed by a SBR reactor. Biosys. Eng. 2012;111:243-250

15. Macé S, Mata-Álvarez J. Utilization of SBR technology for wastewater treatment: an overview. Ind. Eng. Chem. Resour. 2002;41:5539-5553.

16. Obaja D, Macé S, Mata-Álvarez J. Biological nutrient removal by a sequencing batch reactor (SBR) using an internal organic carbon source in digested piggery wastewater. Bioresour. Technol. 2005;96:7-14.

17. Han GB, Lee BH, Lee YW. Development of soil-covered SBR process for small scale sewage treatment. Env. Technol. 2006;27:715-722.

18. Zhu J, Zhang Z, Miller C. A laboratory scale sequencing batch reactor with the addition of acetate to remove nutrient and organic matter in pig slurry. Biosys. Eng. 2006;93:437-446.

19. Apha A. Standard Methods for the Examination of Water and Wastewater, 20th ed. Washington D.C.: American Public Health Association; 1998.

20. Layden MN, Mavinic DC, Kelly HG, Moles R, Bertlett J. Autothermol thermophilic aerobic digestion (ATAD) - Part I: review of origins, design, and process operation. J. Env. Eng. Sci. 2007;6:665-678.

21. Mark CM, Loosdrecht V, Henze M. Maintenance, endogeneous respiration, lysis, decay and predation. Water Sci. Technol. 1999;39:11-20.

22. Yan S, Miyanaga K, Xing X H, Tanjiyan Y. Succession of bacterial community and enzymatic activities of activated sludge by heat-treatment for reduction of excess sludge. Biochem. Eng. J. 2008;39:598-603.

23. Li X, Ma H, Wang Q, Matsumoto S. Isolation, identification of sludge-lysing strain and its utilization in thermophilic aerobic digestion for waste activated sludge. Bioresour. Technol. 2009;100:2475-2483.

24. Lee JW, Lee HW, Kim SW. Nitrogen removal characteristics analyzed with gas and microbial community in thermophilic aerobic digestion for piggery waste treatment. Water Sci. Technol. 2004;49:349-357.

25. Yu GH, He PJ, Shao LM, Zhu YS. Extracellular proteins, polysaccharides and enzymes impact on sludge aerobic digestion after ultrasonic pretreatment. Water Res. 2008;42:1925-1934. 26. Willers HC, Derikx JL, Ten Have PJ, Vijn TK. Emission of 
ammonia and nitrous oxide from aerobic treatment of veal calf slurry. J. Agricul. Eng. Res. 1996;63:345-352.

27. Hutchison ML, Walters LD, Avery SM, Munro F, Moore A. Analyses of Livestock Production, Waste Storage, and Pathogen Levels and Prevalences in Farm Manures. Appl. Env. Microb. 2005;71:1231-1236.

28. Pagilla KR, Kim HJ, Cheunbarn T. Aerobic thermophilic and anaerobic mesophilic treatment of swine waste. Water Res. 2000;34:2747-2753.

29. Ginnivan MJ, Woods JL, O’Callaghan JR. Thermophilic aerobic treatment of pig slurry. J. Agricul. Eng. Res. 1981;26:455-466.

30. Vanotti MB, Szogi AA, Millner PD, Loughrin JH. Development of a second-generation environmentally superior technology for treatment of swine manure in the USA. Bioresour. Technol. 2009;100:5406-5416.
31. Vanotti MB, Millner PD, Hunt PG, Ellison AQ. Removal of pathogen and indicator microorganisms from liquid swine manure in multi-step biological and chemical treatment. Bioresour. Technol. 2005;96:209-214.

32. Béline F, Daumer ML, Loyon L, Pourcher AM, Dabert P, Guiziou F, Peu P. The efficiency of biological aerobic treatment of piggery wastewater to control nitrogen, phosphorus, pathogen and gas emissions. Water Sci. Technol. 2008;57:1909-1914.

33. Lee SI., Park JH., Ko KW., Koopman B. Effect of fermented swine wastes on biological nutrient removal in sequencing batch reactors. Water Res. 1997;97:1807-1812.

34. Kuo CM, Chen TY, Lin TH, Kao CY, Lai JT, Chang JS, Lin CS. Cultivation of Chlorella sp. GD using piggery wastewater for biomass and lipid production. Biore. Technol, 2015;194: 326-333. 